\title{
Karakteristik Taman Flora Sebagai Sarana Pendidikan Bagi Masyarakat di Kota Surabaya
}

\author{
Aurora Exacty Pradana, Ardy Maulidy Navastara \\ Departemen Perencanaan Wilayah dan Kota, Fakultas Arsitektur, Desain dan Perencanaan, Institut \\ Teknologi Sepuluh Nopember \\ e-mail: ardy.navastara@urplan.its.ac.id
}

\begin{abstract}
Abstrak-Taman Flora merupakan salah satu taman di Surabaya yang potensial dalam pemenuhan hak masyarakat yang timbul dari kehadiran ruang publik hal ini terlihat dari lokasinya yang strategis, keberagaman fasilitas, dan dipilihnya taman tersebut sebagai lokasi pembelajaran di luar kelas. Namun di sisi lain Taman Flora belum optimal bagi anak usia 7-14 tahun apabila dilihat dari keberagaman program dan fasilitas yang mendukung pendidikan, serta kemudahan akses bagi seluruh kelompok masyarakat. Taman Kota di Surabaya memiliki karakteristik yang berbeda-beda khususnya pada Taman Flora yang berperan sebagai sarana pendidikan, sehingga dilakukan penelitian untuk mengetahui karakteristik Taman Flora. Penelitian ini dilakukan dengan metode analisa deskriptif kualitatif dan analisis gambar, dengan sampel penelitian sebanyak 30 pengunjung berusia 714 tahun. Dari penelitian ini diketahui bahwa Taman Flora mampu mendukung berbagai aktivitas seperti rekreasi, ekonomi, dan pendidikan, namun taman ini masih memiliki kekurangan yaitu belum terakomodasinya aksesibilitas bagi kelompok difabel dan belum adanya program pendidikan dan olahraga yang dapat mendekatkan anak-anak pada alam dan berinteraksi sosial dengan sesamanya.
\end{abstract}

Kata Kunci-Pendidikan, Ruang Publik, Taman Flora.

\section{PENDAHULUAN}

$\mathrm{R}$ UANG publik merupakan suatu wadah yang dapat menampung aktivitas tertentu dari manusia, baik secara individu maupun berkelompok [1]. Ruang publik memiliki berbagai fungsi yaitu fungsi sosial sebagai sarana interaksi sosial, fungsi ekonomi sebagai wadah untuk menampung aktivitas ekonomi, fungsi ekologis sebagai sarana untuk menciptakan lingkungan yang sehat, dan fungsi pendidikan sebagai sarana bagi masyarakat untuk mengakses pengetahuan [2]. Ruang publik menjadi fokus pembangunan bagi seluruh dunia, hal ini terlihat dari PBB yang memiliki komitmen untuk menyediakan ruang publik di kota-kota pada negara berkembang di dunia yang termaktub dalam Sustainable Development Goals / SDG's tahun 2016-2030 yang dijabarkan melalui dokumen resmi New Urban Agenda [3].

Kota-kota di Asia dalam beberapa tahun terakhir melakukan pembenahan terkait dengan ruang publik perkotaan, salah satunya adalah Kota Surabaya. Semenjak tahun 2010, Surabaya mulai membenahi ruang publik yang dimiliki dengan memperbaiki atau menambahkannya. Ruang publik yang menjadi fokus Kota Surabaya adalah taman kota. Tercatat bahwa Surabaya memiliki 70 Taman aktif yang masih akan ditambah oleh pemerintah kota [4].

Salah satu taman di Surabaya yang menjadi destinasi masyarakat adalah Taman Flora. Taman Flora merupakan salah satu taman yang potensial dalam pemenuhan hak masyarakat yang timbul dari kehadiran ruang publik. Dengan banyaknya fasilitas yang ditawarkan dan lokasinya yang strategis, maka Taman Flora mampu berperan dalam memenuhi kebutuhan masyarakat akan rekreasi, ekonomi, terutama pendidikan. Dengan banyaknya fasilitas yang ditawarkan dan lokasinya yang strategis, maka Taman Flora mampu berperan dalam memenuhi kebutuhan masyarakat akan rekreasi, ekonomi, terutama pendidikan. Berdasarkan data pemanfaatan taman pada bulan Januari dari 34 kunjungan yang terdaftar, 20 diantaranya untuk study tour atau pembelajaran. Sedangkan pada bulan Februari 2018 diketahui bahwa dari 47 kunjungan, 29 diantaranya berupa aktivitas pembelajaran diluar ruangan yang dilakukan oleh lembaga pendidikan seperti TK, SD, hingga SMA [5]. Data tersebut menunjukkan bahwa fungsi pendidikan pada Taman Flora sudah berjalan, terbukti dengan banyaknya lembaga pendidikan yang memanfaatkan taman tersebut untuk melakukan pembelajaran di luar kelas. Data di atas juga menunjukan bahwa Taman Flora memiliki potensi sebagai salah satu sarana pendidikan terutama untuk anak usia 7-14 tahun.

Fasilitas yang disediakan taman tentunya akan menunjang fungsi Taman Flora sendiri. Taman Flora merupakan salah satu taman yang berfungsi sebagai lokasi pendidikan di Surabaya, walaupun taman ini telah memiliki fasilitas fisik berupa bangunan (Taman Baca dan Broadband Learning Center). Namun taman ini masih memiliki kekurangan yaitu Taman Flora belum menyediakan fasilitas pendidikan yang membuat pengunjung langsung bersentuhan dengan alam. Dengan fungsinya sebagai sarana pendidikan tentunya Taman Flora harus mengoptimalkan fasilitas yang ada, baik itu fasilitas bermain maupun olahraga untuk mendukung aktivitas pendidikan. Kurang optimalnya taman juga terlihat dari akses dalam taman yang belum ramah bagi kelompok difabel, padahal ruang publik harus dapat diakses oleh seluruh kelompok masyarakat dengan mudah. Taman Flora juga belum memiliki masterplan. Dokumen tersebut harus dimiliki karena digunakan sebagai pedoman dalam mengelola dan mengembangkan taman. Belum jelasnya status lahan taman juga membuat taman ini rawan untuk diambil oleh pihak swasta dengan kemungkinan terburuknya dijadikan sebagai tempat perdagangan dan jasa karena Taman Flora memiliki lokasi yang strategis.

Dari latar belakang tersebut, diperlukan penelitian untuk mengetahui karakteristik Taman Flora sehingga mempermudah dalam mengoptimalkan taman tersebut. Penelitian ini dilakukan dengan mengidentifikasi karakteristik dari Taman Flora sendiri maupun dari sisi pengunjung. Hal ini karena Potensi pengguna ruang publik 
harus diidentifikasi dan dilibatkan, baik dalam pengembangan program dan desain. Mengamati bagaimana sebuah taman digunakan dan mengetahui persepsi pengunjung terhadap taman tersebut merupakan kunci dalam memahami perubahan apa yang dapat dilakukan untuk mengubah taman menjadi lebih baik [6]. Dalam hal ini, pengunjung yang dimaksud adalah anak-anak usia 7-14 tahun (usia SD - SMP) sehingga keberadaan mereka sangat penting dalam penelitian ini.

\section{METODE PENELITIAN}

Tabel 1.

Variabel Penelitian

\begin{tabular}{ll}
\hline \multicolumn{1}{c}{ Variabel } & \multicolumn{1}{c}{ Variabel Penelitian } \\
\hline \multirow{3}{*}{ Kenyamanan Variabel } \\
\multirow{3}{*}{ Aktivitas } & Kebersihan \\
& Vegetasi \\
& Desain rancang taman \\
& Keberagaman aktivitas \\
& Fasilitas pendidikan \\
& Fasilitas bermain \\
Fasilitas & Fasilitas bersantai \\
& Fasilitas penunjang \\
& Fasilitas olahraga \\
Kenyamanan & Petugas keamanan \\
& Lingkungan yang aman \\
Kebijakan & Pengolaan taman \\
& Kedekatan dengan fasilitas umum lain \\
& Terkoneksi dengan transportasi \\
Aksesibilitas & Terkoneksi dengan aktivitas lain \\
& Kemudahan akses \\
& Sirkulasi kendaraan \\
Penggunan lahan & Jenis penggunaan lahan sekitar \\
\hline \hline
\end{tabular}

\section{A. Jenis dan Pendekatan Penelitian}

Pendekatan yang digunakan dalam penelitian ini adalah pendekatan rasionalistik dengan jenis penelitian menggunakan metode penelitian campuran (kualitatif dan kuantitatif).

\section{B. Variabel Penelitian}

Variabel yang digunakan dalam penelitian ini adalah sebagai berikut :

\section{Metode Pengumpulan Data}

Pengumpulan data dilakukan dengan metode pengumpulan data primer dan sekunder. Metode pengumpulan data primer dilakukan dengan cara observasi pada Taman Flora dan wawancara pada pengunjung taman. Pengunjung taman yang diwawancara adalah anak-anak berusia 7-14 tahun dan telah mengunjungi Taman Flora minimal dua kali dalam satu bulan. Selain melakukan wawancara pada pengunjun, peneliti juga melakukan wawancara pada dinas terkait yaitu DKRTH Kota Surabaya dan Kantor Taman Flora. Peneliti juga melakukan pengumpulan gambar yang bertujuan untuk mengetahui persepsi anak-anak terhadap Taman Flora. Metode pengumpulan data sekunder dilakukan dengan mengumpulkan data dari instansi pemerintah yaitu DKRTH Kota Surabaya dan Taman Flora.

\section{Metode Analisis Data}

Dalam menganalisis karakteristik Taman Flora, peneliti menggunakan teknik analisa deskriptif kualitatif dan analisis gambar. Analisa deskriptif ini digunakan untuk menggambarkan atau mendeskripsikan suatu data yang menerangkan keadaaan, gejala, atau persoalan, yang disajikan dalam bentuk tabel, nilai, ataupun grafik. Analisis gambar dilakukan untuk mengetahui persepsi anak-anak terhadap Taman Flora Gambar dapat digunakan sebagai metode analisis karena dapat memunculkan pemikiran dan pandangan anak-anak pada berbagai subjek, mengumpulkan perspektif mereka dapat digunakan sebagai informasi yang berharga terkait bagaimana anak-anak memandang dunia disekitar mereka [7].

\section{HASIL DAN DISKUSI}

Taman Flora terletak di Jalan Manyar No.80 A Bratang yang terletak pada Kelurahan Barata Jaya, Kecamatan Gubeng dan memiliki batas sebagai berikut :

Sebelah utara : Jalan Ngagel Jaya Selatan

Sebelah timur : Jalan Raya Manyar dan Kelurahan Menur Pumpungan

Sebelah barat : Jalan Ngagel Jaya Selatan

Sebelah selatan : Jalan Raya Manyar

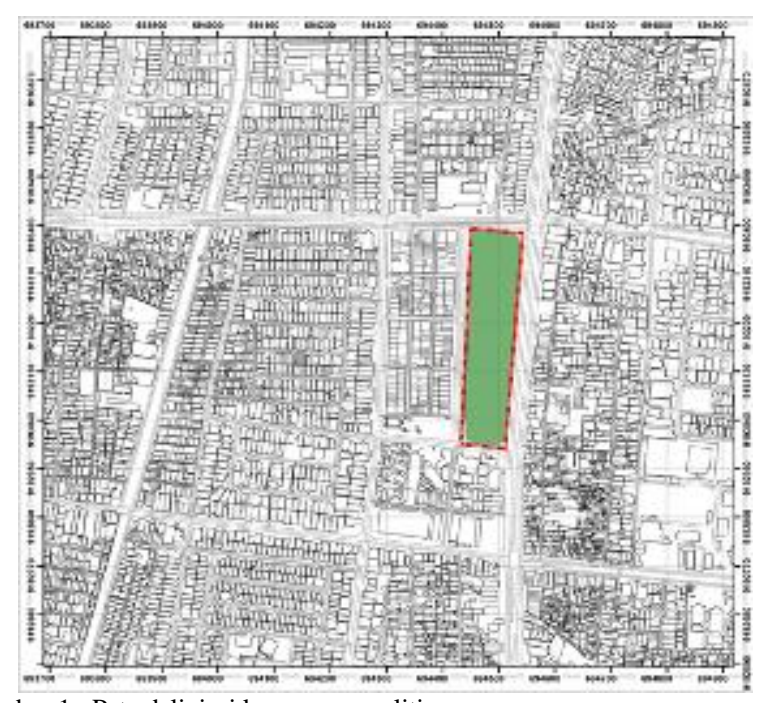

Gambar 1. Peta deliniasi kawasan penelitian.

Taman Flora diresmikan pada tahun 2007 dan memiliki luas sebesar $33.810 \mathrm{~m}^{2}$. Dengan taman yang luas, kegiatan yang dapat dilakukan pada Taman Flora memang beragam, baik berupa bersepeda atau berpiknik bersama dengan keluarga. Menurut pengelola dari Taman Flora terdapat lebih dari 100 pengunjung yang datang dalam sehari. Waktu kunjungan pun bervariasi mulai dari pagi hingga sore hari, namun pengunjung lebih didominasi pada sore hari atau pada siang hari sepulang sekolah dan saat istiharat kantor. Untuk jam operasional dari Taman Flora sendiri adalah pukul 07.00 - 17.00 WIB. Fasilitas yang disediakan pada Taman Flora didominasi oleh permainan outdoor dan outbond.

Berikut ini merupakan pembahasan mengenai karakteristik dari Taman Flora :

1) Kenyamanan

Kenyamanan terdiri dari dua sub variabel yaitu kebersihan, vegetasi dan desain taman.

a. Kebersihan

Taman Flora telah dibersihkan setiap hari dan taman ini juga menyediakan tempat sampah bagi pengunjung yang ditempatkan pada setiap bangunan, area bermain, area olahraga, dan pintu masuk dan di sepanjang pathway 
(setiap 6 meter). Kelompok difabel pun dapat dengan mudah mengakses tempat sampah yang tersedia di taman. Namun terdapat timbulan bau dari TPS Bratang yang membuat pengunjung merasa terganggu.

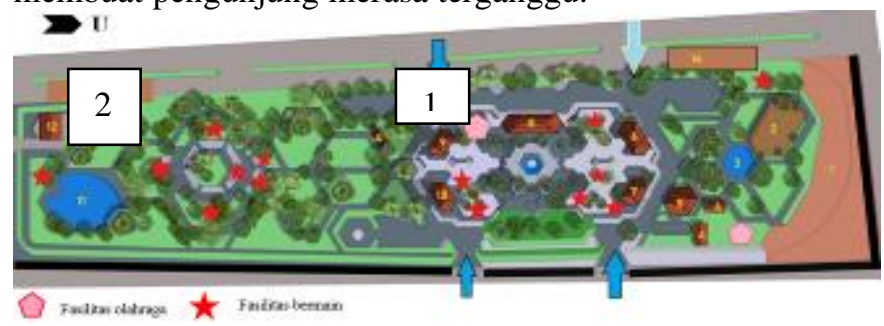

Gambar 2. Lokasi tempat sampah dan TPS Bratang.

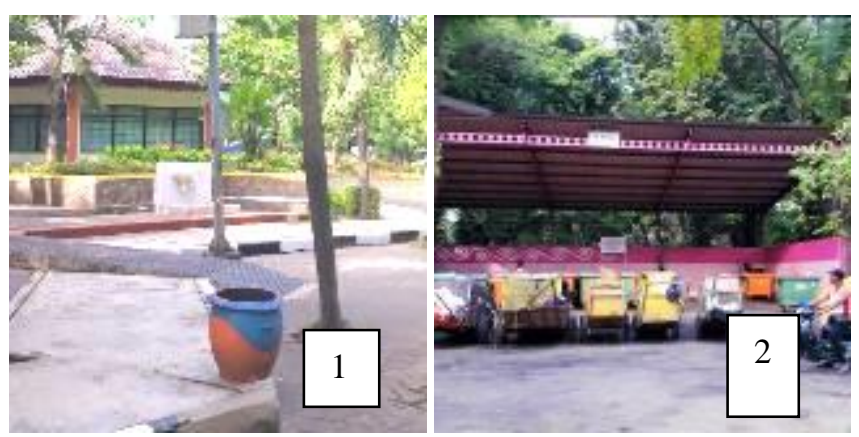

Gambar 3. Tempat sampah pada pathway (kiri) dan TPS Bratang (kanan).

\section{b. Vegetasi}

Taman Flora memiliki vegetasi yang meneduhkan dan mengurangi kebisingan dari kendaraan yang melintas sehingga membuat responden nyaman untuk beraktivitas. Tumbuhan yang ada pada taman juga aman karena tidak berduri, mudah patah, dan beracun.

c. Desain Rancang Taman

Desain Taman Flora dibuat menyerupai sarang lebah desain tersebut memberikan rasa nyaman pada pejalan kaki dan membuat mereka dapat berjalan-jalan lebih lama. , sedangkan kelemahannya adalah taman ini tidak dapat menyediakan fasilitas berupa lapangan olahraga sebagai lokasi bermain anak-anak.

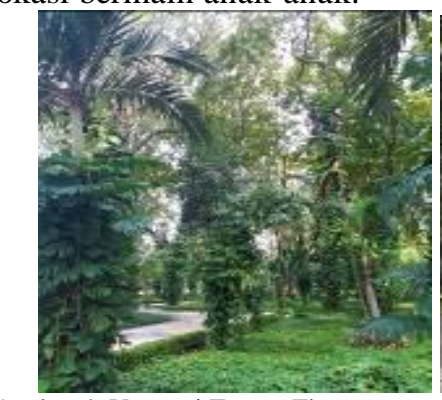

Gambar 4. Vegetasi Taman Flora.

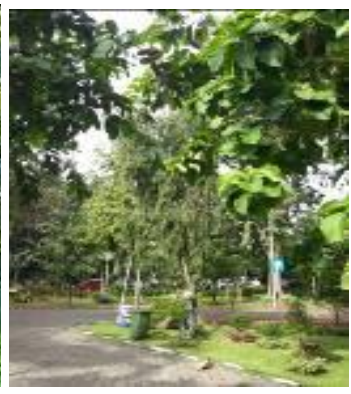

\section{2) Aktivitas}

Taman Flora mampu menampung mendukung aktivitas yang beragam terutama aktivitas pendidikan, namun masih perlu adanya adanya program-program untuk pengunjung secara berkala.

\section{3) Fasilitas}

Fasilitas pada taman terbagi menjadi 5 sub variabel yaitu fasilitas pendidikan, fasilitas bermain, fasilitas bersantai, fasilitas penunjang, dan fasilitas olahraga.

a. Fasilits Pendidikan

Fasilitas pendidikan tersebar diseluruh elemen taman yaitu terdapat taman baca, Broadband Learning Center (BLC), rumas kompos, kandang rusa, burung, taman toga dan fasilitas tersebut mendukung fungsi pendidikan pada Taman Flora. Namun, belum adanya program-program yang dapat diakses seluruh masyarakat membuat fungsi pendidikan pada taman kurang maksimal.

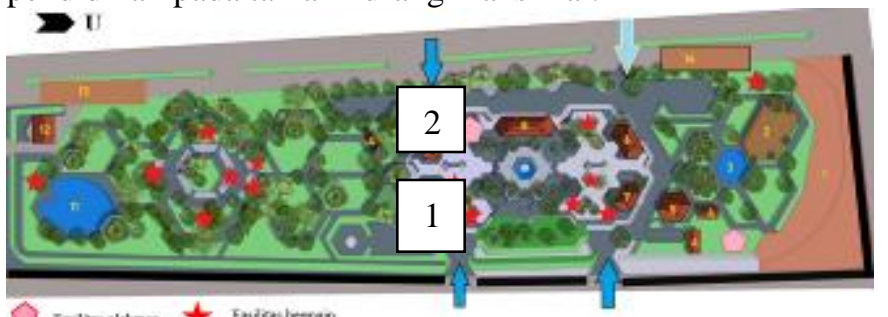

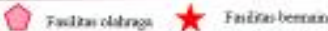

Gambar 5. Lokasi fasilitas pendidikan Taman Flora.
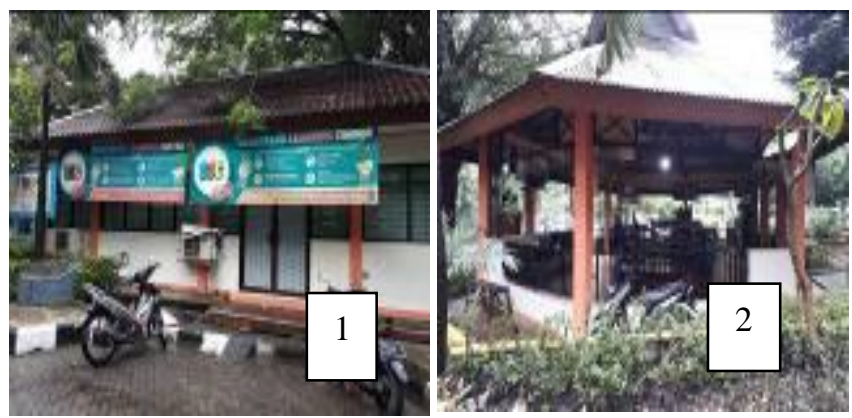

Gambar 6. Fasilitas Pendidikan Taman Flora.

\section{b. Fasilitas Bermain}

Fasilitas bermain pada taman sebaiknya dilengkapi dengan bench bagi orangtua, pada Taman Flora sudah dilengkapi dengan bench bagi orangtua untuk mengawasi anaknya. kelemahannya adalah fasilitas bermain pada taman mulai berkarat dan lapuk sehingga berbahaya bagi anak-anak, serta terbatasnya jenis permainan yang ada pada taman. Menurut responden sendiri, jenis permainan pada Taman Flora kurang bervariasi. Taman Flora sendiri sudah menyediakan permainan bagi kelompok difabel.

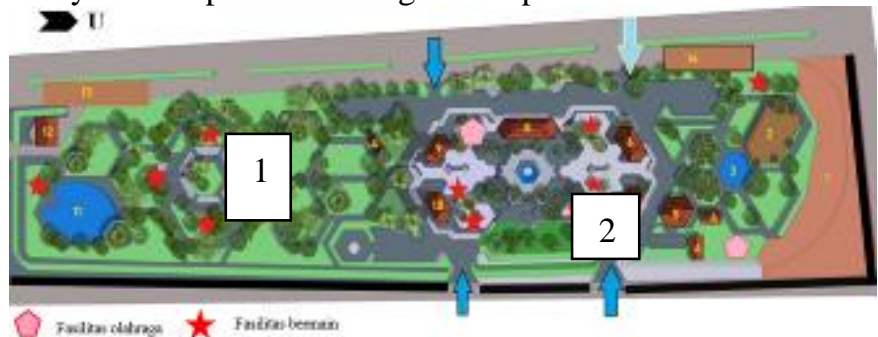

Gambar 7. Lokasi fasilitas bermain Taman Flora.
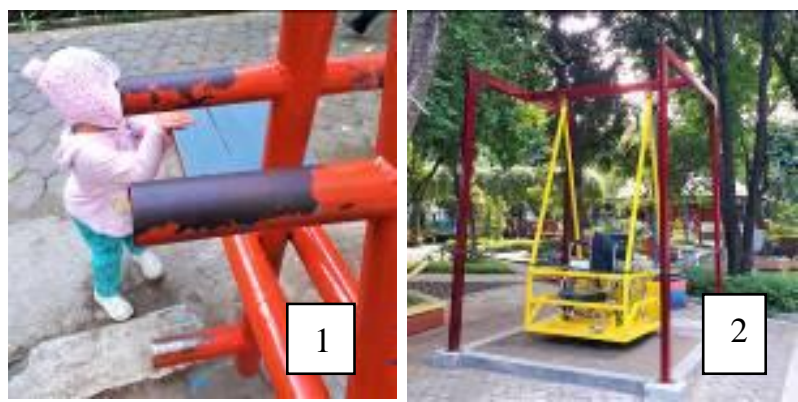

Gambar 8. Fasilitas bermain dengan cat mengelupas (kiri) dan fasilitas bermain untuk kelompok difabel (kanan).

\section{c. Fasilitas Bersantai}

Dalam menyediakan fasilitas bersantai pada taman kota perlu memperhatikan akses bagi kelompok difabel [8]. Pada Taman Flora diketahui bahwa masih adanya fasilitas bersantai yang belum terakses oleh kelompok difabel, serta 
responden belum puas dengan penyediaan fasilitas bersantai yang tidak dapat digunakan berkelompok.

d. Fasilitas Penunjang

Taman Flora telah dilengkapi fasilitas penunjang berupa 2 toilet dan mushalla yang ramah bagi kelompok difabel serta telah dilengkapi dengan rambu-rambu/signage yang berfungsi untuk menunjukkan arah-arah fasilitas penunjang dan atraksi pada taman. Namun pengunjung berpendapat kebersihan pada fasilitas yang tersedia belum maksimal.

\section{e. Fasilitas Olahraga}

Taman Flora telah menyediakan fasilitas olahraga berkualitas yang tahan dengan segala cuaca, fasilitas olahraga juga dilengkapi bench bagi orangtua. Namun responden merasa taman ini perlu menambahkan fasilitas olahraga lain seperti lapangan dan jalur bersepeda.

\section{Keamanan}

Keamanan pada taman terbagi menjadi 2 sub variabel yaitu petugas keamanan serta lingkungan yang aman.

a. Petugas Keamanan

Tabel 2.

Jarak Taman dengan Fasilitas Umum

\begin{tabular}{ll}
\hline \hline Fasilitas Umum & Jarak dari Taman Flora \\
\hline Polsek Gubeng & $2-4$ menit berjalan kaki \\
Terminal Bratang & $5-10$ menit berjalan kaki \\
SMP Dr. Soetomo & 10 menit berjalan kaki \\
SMA Dr. Soetomo & 10 menit berjalan kaki \\
Sekolah Kreatif & 15 menit berjalan kaki / 5 menit berkendara \\
Muhammadiyah 16 & 15 menit berjalan kaki / 5 menit berkendara \\
SMPN 48 Surabaya & 15 menit berjalan kaki / 5 menit berkendara \\
SDN Ngagel Rejo V &
\end{tabular}

Sumber : Google Maps, 2018.

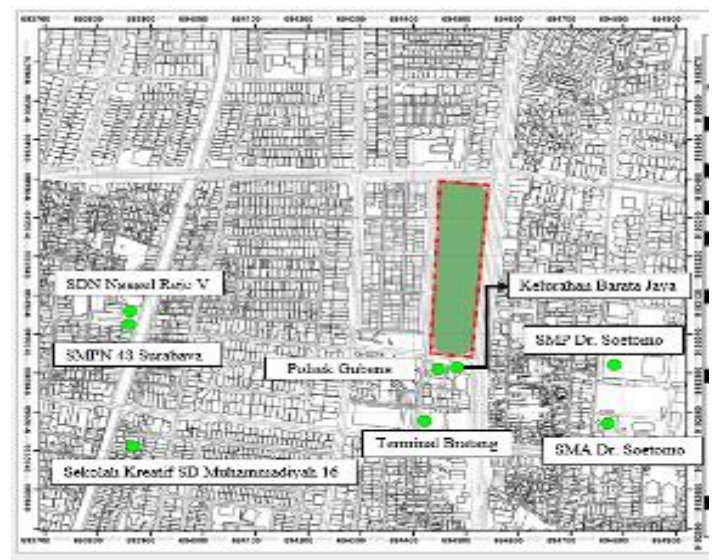

Gambar 12. Peta Lokasi Fasilitas Umum

Sumber : Penulis, 2018

Taman Flora sendiri memiliki 6 petugas kemanan yang bertugas selama masa beroperasinya taman yaitu pukul 07.00 - 17.00 WIB. Seluruh responden juga merasa keberadaan Linmas pada Taman Flora mampu memberikan rasa aman. Namun salah satu linmas mengungkapkan 6 petugas pada taman dirasa sedikit karena masih adanya bagian-bagian taman yang belum bisa terpantau terutama pada saat ramai.

\section{b. Lingkungan yang Aman}

Taman Flora dikelilingi oleh 2 jenis pagar yaitu pagar besi setinggi 1,5 meter dan pagar tanaman dengan tinggi 50 sentimeter, serta terdapat parit yang memisahkan taman dengan lingkungan luar taman. Keberadaan pagar yang mengelilingi taman membuat responden merasa aman ketika beraktivitas di taman.

\section{Kebijakan}

Taman Flora dikelola oleh UPTD Taman Flora berdasarkan Peraturan Walikota Nomor 78 Tahun 2008. Adapun tugas dari UPTD Taman Flora adalah sebagai berikut :

- Pelaksanaan penyusunan program

- Pengelolaan dan pemeliharaan sarana dan prasarana tama

- Pelaksanaan pengelolan tanaman

- Pelaksanaan ketatausahaan UPTD

- Pelaksanaan evaluasi dan pelaporan pelaksanaan tugas

- Pelaksanaan tugas-tugas lain yang diberikan oleh Kepala Dinas sesuai tugas dan fungsinya

Hal yang perlu ditingkatkan oleh UPTD Taman Flora sendiri adalah pelaksanaan penyusunan program. Karena sampai saat ini Taman Flora belum memiliki program pendidikan untuk masyarakat dari berbagai kalangan. Taman Flora saat ini juga belum memiliki masterplan taman, sehingga pengelolaannya saat ini hanya berdasarkan Peraturan Walikota Nomor 78 Tahun 2008.

\section{Aksesibilitas}

Aksesibilitas pada taman terbagi menjadi 5 sub variabel yaitu kedekatan dengan fasilitas umum lain, terkoneksi dengan transportasi, terkoneksi dengan aktivitas lain, kemudahan akses, dan sirkulasi kendaraan.

a. Kedekatan dengan Fasilitas Umum

Terdapat tujuh Fasilitas umum yang dekat dengan Taman Flora dimana semuanya berjarak tidak lebih dari 4 kilometer dengan jarak tempuh tidak lebih dari 15 menit.

b. Terkoneksi dengan Transportasi

Taman Flora sudah terkoneksi dengan transportasi umum ditandai dengan kedekatannya dengan terminal dan dilalui trasnportasi umum yaitu UBB, Q, JBM, RT, dan S. Namun Taman Flora belum memiliki halte pemberhentian khusus, walaupun dilewati oleh lima jenis rute angkutan umum.

c. Terkoneksi dengan Aktivitas lain

Aktivitas yang mengelilingi Taman Flora adalah kegiatan perdagangan jasa seperti Ruko RMI, pasar bunga dan Pasar Burung Bratang. Kegiatan tersebut berdampak pada tumbuhnya kegiatan perdagangan lain yaitu adanya Sentra Kuliner RMI dan Wisata Kuliner Bratang Binangun. Selain itu juga terdapat Perumahan Bratang Binangun dan perkampungan pada Jl. Manyar, masyarakat pun berkunjung ke taman untuk berekreasi, mengerjakan tugas, dan bermain karena dekat dengan rumahnya.

\section{d. Kemudahan Akses}

Kondisi pedestrian way dan pathway pada Taman Flora masih belum ramah terhadap kelompok difabel, sementara pedestrian way tidak terhubung dengan pintu masuk taman, begitu pula bagi pejalan kaki yang berasal dari Jl. Manyar merasa kesulitan karena tidak adanya alat bantu penyeberangan sementara kendaraan pada jalan tersebut melaju dengan kencang.

\section{e. Sirkulasi Kendaraan}

Taman Flora tidak memiliki rambu petunjuk arah yang menunjukkan pintu masuk taman sehingga pengunjung 
kebingungan terkait arah masuk Taman Flora yang sebenarnya. Selain itu pada Jl. Ngagel Jaya Selatan yang terdiri dari 2 jalur, ditutup sebagian untuk sentra kuliner RMI, sehingga pengunjung hanya dapat menggunakan 1 jalur sisanya yang juga digunakan sebagai tempat parkir

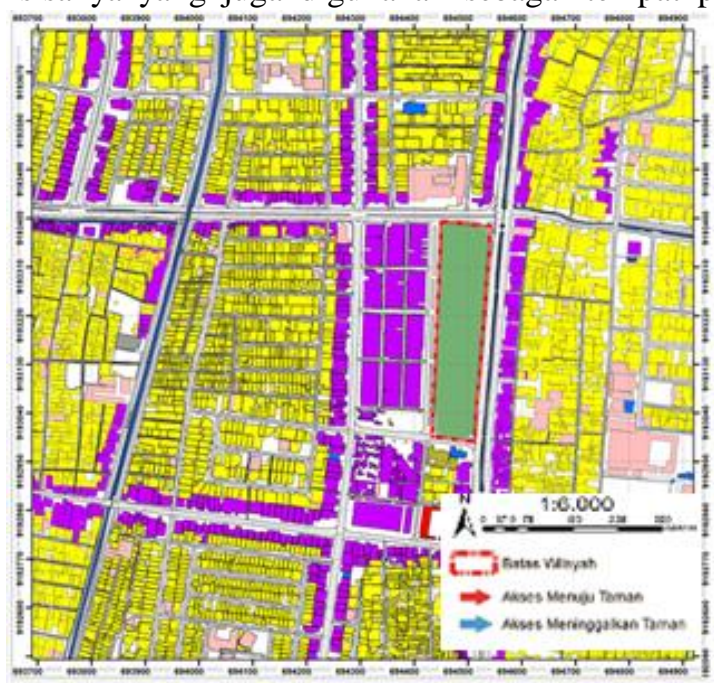

Gambar 14. Peta Penggunaan Lahan di Sekitar Taman

Sumber: Penulis, 2018

\section{Penggunaan Lahan}

Taman Flora dikelilingi dengan penggunaan lahan berupa perdagangan dan jasa serta perumahan. Aktivitas perdagangan Jasa yang bersinggungan langsung dengan taman adalah Ruko RMI. Dari hasil observasi diketahui terdapat pintu masuk dan keluar ruko RMI yang mengarah langsung ke Taman Flora, juga terdapat bangunan ruko yang menghadap ke taman, fasilitas umum berupa kepolisian, dan Kantor Kelurahan Barata Jaya juga menghadap taman. Dengan dikelilinginya taman dan menjadi center bagi guna lahan lainnya merupakan salah satu kelebihan dalam menarik pengunjung untuk datang ke taman.

Tabel 3.

Komponen yang Tergambar Oleh Anak-anak

\begin{tabular}{ll}
\multicolumn{2}{c}{ Komponen yang Tergambar Oleh Anak-anak } \\
\hline \hline Komponen & Jumlah \\
\hline Pepohonan & 10 \\
Tanaman bunga & 9 \\
Bangku Taman & 6 \\
Fasilitas olahraga & 12 \\
Fasilitas Bermain & 1 \\
Kolam & 3 \\
Pagar & 1 \\
Gazebo & 1 \\
Patung & 1 \\
\hline \hline Sumber : Hasil Analisa,, 2018.
\end{tabular}

Selain melakukan observasi dan wawancara, peneliti juga mengidentifikasi persepsi anak mengenai keinginan dan ide mereka terhadap ruang publik yaitu Taman Flora. Sumber data didapatkan melalui pengumpulan gambar. Proses dari pengumpulan gambar sendiri yaitu peneliti memberikan gambaran terhadap hal-hal yang akan digambar oleh anak-anak dengan memberikan contoh mengenai gambaran terkait taman yang ideal dari kacamata peneliti baik berupa gambar maupun video, peneliti juga membebaskan anak-anak untuk menggambar obyek yang mereka inginkan di taman dan kegiatan yang mereka ingin motor dan mobil pada badan jalan, jalan tersebut juga digunakan 2 arah sehingga menimbulkan kemacetan didepan pintu masuk Taman Flora pada saat ramai pengunjung.

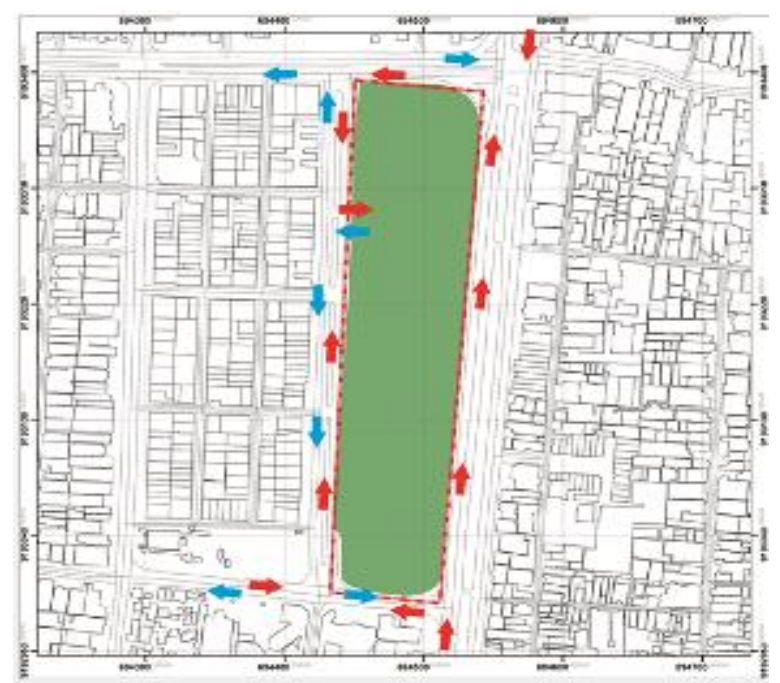

Gambar 13. Peta Sirkulasi Taman Flora.

Sumber: Penulis, 2018

lakukan pada taman. Peneliti sendiri terus mendampingi anak-anak disepanjang proses menggambar.

Gambar yang dikumpulkan akan diinterpretasi komponen apa saja yang tergambar, suasana dan keunikan yang ada pada gambar tersebut. Komponen yang digambar oleh anak-anak selanjutnya disajikan dalam tabel berikut ini

Mayoritas anak-anak menggambar rung publik yang memiliki pepohonan, taman bunga, fasilitas olahraga, bangku taman, kolam ikan. Hal ini menunjukkan bahwa mereka menginginkan ruang publik yang mampu mengakomodasi kegiatan olahraga dan bersantai. Gambar tersebut juga menunjukkan komponen apa saja yang mereka inginkan untuk ada di Taman Flora. Dari tabel tersebut kita mengetahui bahwa anak-anak berpendapat bahwa aktivitas olahraga di taman ini belum ditunjang secara maksimal. Fasilitas olahraga mampu menawarkan sebuah interaksi sosial, dimana interaksi sosial mampu mengembangkan kebahagiaan dan kecerdasan anak [9].

\section{KESIMPULAN}

Kesimpulan yang didapat dari hasil pembahasan mengenai identifikasi karakteristik Taman Flora adalah sebagai berikut:

1) Kebersihan pada Taman Flora tetap terjaga dengan dibersihkannya taman setiap harinya, namun pengunjung masih tidak puas dengan kebersihan toilet taman. TPS Bratang juga menimbulkan bau tidak sedap sehingga mengganggu kenyamanan taman

2) Vegetasi pada taman telah memberikan rasa teduh dan mengurangi kebisingan dari kendaraan yang melintas. Namun responden merasa diperlukan penambahan vegetasi berupa taman bunga.

3) Fasilitas pendidikan pada taman telah tersedia di seluruh elemen taman berupa gedung, vegetasi, dan 
hewan. Namun Taman Flora belum memiliki program pendidikan yang terjadwal dan membuat pastisipan langsung bersentugan dengan alam.

4) Fasilitas olahraga belum dilengkapi dengan fasilitas yang dapat membuat anak-anak mampu berinteraksi sosial dengan sesamanya.

5) Aksesibilitas kelompok difabel masih belum mampu didukung oleh taman, masih ada pathway dan fasilitas pada taman yang tidak dilengkapi akses khusus bagi kelompok difabel.

6) Aksesibilitas di luar taman belum maksimal terlihat dari pedestrian way yang terputus dan belum adanya alat bantu penyeberangan bagi pengunjung taman.

7) Taman Flora berada di lokasi strategis dan dilewati oleh angkutan umum.

\section{DAFTAR PUSTAKA}

[1] R. Hakim and H. Utomo, Komponen Perancangan Arsitektur Lansekap: Prinsip - Unsur dan Aplikasi Desain. Jakarta: Bumi
Aksara, 2003.

[2] Amalia, "Tingkat Keberhasilan Ruang Terbuka Publik pada Perumahan Taman Setia Budi Indah,” Medan, 2012.

[3] C. Roque, "Why Asia's Cities Need Public Space," jllrealviews.com. [Online]. Available: https://www.jllrealviews.com/trends/asias-cities-need-publicspaces/. [Accessed: 17-Oct-2016].

[4] R. Nurwawati, "Pemkot Surabaya Tambah Taman Baru, ini Lokasinya," $2017 . \quad$ [Online]. Available: http://surabaya.tribunnews.com/2017/01/31/2017-pemkotsurabaya-tambah-28-taman-baru-ini-lokasinya?page $=1$.

[5] Dinas Kebersihan dan Ruang Terbuka Hijau Kota Surabaya (tidak dipublikasikan), "Data Pengunjung Taman Flora bulan Januari Februari 2018," Surabaya, 2018.

[6] F. Kent, "Creating Great Urban Park," Project For Public Spaces. [Online]. Available: https://www.pps.org/article/creating-greaturban-parks. [Accessed: 31-Dec-2008].

[7] P. Duncan, "Drawing as a Method for Accessing Young Children's Perspective in Research," Stirling, 2013.

[8] C. Commission, "Park/Public Space Facility Standards," City of Irvine, 2005

[9] E. David and S. Ryan, "The Roles of an Urban Parks System," 2016. 